\title{
HYALURONIC ACID: OBTAINING, PROPERTIES AND APPLICATION"
}

\author{
Larisa Zadorojnâi ${ }^{1}$, Alexandru Zadorojnâi ${ }^{2}$ \\ ${ }^{1}$ Technical University of Moldova, E-mail: larisazadorojnyi@yandex.ru \\ ${ }^{2}$ State University of Moldova, str. A. Mateevici 60 A, MD 2009, Chișinău, R. Moldova
}

\begin{abstract}
Properties and methods for obtaining hyaluronic acid and its derivatives from raw material of animal origin are reviewed. The importance and practical application of hyaluronic acid in various fields are discussed.
\end{abstract}

Keywords: hyaluronic acid, obtaining methods, natural sources.

\section{Introduction}

The production and usage of hyaluronic acid (HA) is growing worldwide. In Moldova, hyaluronic acid is less known as pharmaceutical and cosmetic component.

Currently there are many known products that contain HA, eg Juviderm, Restylane, Perlan, HYLAFORM, etc. HydraFill., and only Curiozina (Hungary) was recorded in our country.

Ever-increasing demands of hyaluronic acid for pharmaceutical, cosmetic and food industry imposes researches to study and investigate its properties; seek local sources of hyaluronic acid; develop cost-effective methods of production and domestic production of hyaluronic acid; search new chemical derivatives, medicinal and cosmetic preparations on its base.

HA is a precious natural biomaterial, biocompatible, safe and non-allergic. For these reasons HA is one of the most "agreeable" cosmetic ingredient. Emulsions based on it have a smooth soft consistency. Preparats are compatible with human skin and do not cause allergic reactions. Same properties have also sodium, potassium, calcium, zinc, copper and other salts of HA, which are successfully used in cosmetic intdustry. HA is an excellent moisturizer. A molecule of hyaluronic acid can hold up to 500 water molecules, forming a thin film on the skin, which creates an enhanced moisturizing effect. The molecular weight of the preparat increases its hydration effect.

One of the important properties of HA is that its macromolecules can be conjugated with bioactive compounds for pharmaceutical industry. So, hyaluronic acid can be a vehicle for topical medicines, which drives their absorption.

In our country we have enough cheap sources that can be used for hyaluronic acid preparation. The problem is to develop economically efficient methods of obtaining and purification of hyaluronic acid and its derivatives in quantities sufficient to be sold and used in the production of other bioactive compounds based on it.

\section{The properties of hyaluronic acid}

Hyaluronic acid (HA) was discovered about 70 years ago by scientists K. Meyer and J.W. Palmer, in vitreous of bovine eyes. It is a natural biopolymer, class proteoglycans, whose molecule is formed from the remains of $\beta$-D-glucuronic acid and N-acetyl- $\beta$-D-glucosamine linked by $\beta$-glucosidic bonds (1-3 ) - and $\beta$-(1-4), the long unbranched chains (Fig.1). From the primary structure of the macromolecule it can be seen that HA has a repetable disaccharide unit in which glucuronic acid is linked to glucosamine with $\beta$-glycosidic link between atoms $\mathrm{C} 1$ and $\mathrm{C} 3$, respectively [2-acetamido acid-2-deoxy-3-O-( $\beta$-D-glucopiranoziluronic)-D-glucose]. Basic structural unit is repeated in macromolecular chain is a very rigid chain segment with a length of $11.98 \AA$. Spatial distribution of anionic groups and their degree of ionization contribute to the conformation of the molecule due to mutual electrostatic rejection of negative duties along the polysaccharide backbone. Tertiary structure of HA in concentrated solutions, gels and solid, is influenced by the large number of hydrogen bonds inter- and intramolecular polar groups of abundant, such as: $-\mathrm{OH},-\mathrm{COC}-,>\mathrm{C}=\mathrm{O}$, $-\mathrm{NH}_{2},-\mathrm{COO}$, etc.. Structure can be influenced also by hydrophobic interactions of protein fragments. The degree of polymerization and molecular weight varies by tissue type, the process of obtaining so.

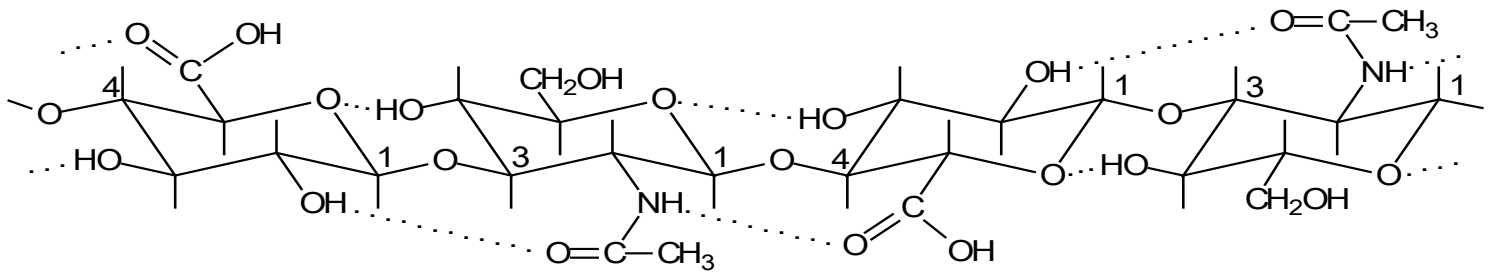

Fig. 1. Chemical structure of hyaluronic acid

The name of HA reflects its transparent nature (the Greek word for glass is hyalos) and the content of one of uronic acids (glucuronic acid).

\footnotetext{
ף This article is an extended abstract of a communication presented at the Conference Ecological Chemistry 2012
} 
Hyaluronic acid is a compound present in the human body. It is one of the main constituents of the extracellular matrix of connective tissue and it is concentrated in synovial fluids, heart valves, eyes, cartilage.

In pure form HA is a white odorless powder soluble in water and insoluble in organic solvents with high viscosity. Specific rotation in aqueous solutions is $-(70-80)^{\circ}$. HA is a polyelectrolyte which $\mathrm{pK}_{\mathrm{HA}}=3.21$. A molecule of $\mathrm{HA}$ is able to retain about 200-500 molecules of $\mathrm{H}_{2} \mathrm{O}$. It has a high specific hydrodynamic volume. The molecule form depends on the $\mathrm{pH}$ and ionic strength of the solution. It was found that as the result of electrophoresis for an ionic force of 0.12 only $14 \%$ of ionized groups are effective, and for an ionic force of 0.02 already $80 \%$ of these groups are effective [1].

Chemical and spatial structure of the macromolecule, high molecular weight, high viscosity of the solution and hydrophilic qualities are important biological properties of HA. Due to these properties, HA has various biological functions and roles in animal bodies such as: participation in embryogenesis and morphogenesis processes, intercellular relationships and communication, mechanical strength of tissues, reducing friction in biomechanical systems, formation and proper function of cartilages, formation and maintenance of transparent structures of the eye, the permeability of biological membranes including vascular walls, water retention [2].

Biological researchs have shown no toxic properties, irritating, allergenic. A comparative study was conducted on biocompatibility and safety of HA obtained from three natural sources: umbilical cord, cockscomb and bovine vitreous [3].

\section{The importance and usage areas of hyaluronic acid}

Due to its properties, HA is one of the most attractive biomaterials for pharmaceutical and cosmetic industry

Hyaluronic acid provides lubrication and hydration of connective tissues, including those of the skin. In the absence of lubrication and hydration of tissue and lose elasticity if skin leads to wrinkles and creases.

Due to its structure, HA form a film on the skin invisible, transparent and elastic, while acting in depth in the tissue, cartilages and joints. Its role is to keep the most important characteristics of young and healthy skin: suppleness, elasticity and tone. HA capacity to restore the interstitial matrix and liquid skin turgor alterations and wrinkles is successfully used for "rejuvenating" skin.

HA is a glycosaminoglycan, an essential component of extra cellular space, in which the collagen and elastin fibers are suspended. HA has an increased capacity to retain water, like a "sponge" that allows maintaining hydration, elasticity, skin firmness. Unfortunately, body's ability to produce hyaluronic acid decreases with age, and so the skin tissue becomes dehydrated, wrinkled and tonicity diminishes. HA injections are used more than 12 years in Europe and gradually replaced the injection of bovine collagen, which is sometimes complicated and required tests prior allergic reactions. Being a natural filler, it has a very low rate of allergic reactions $-0.06 \%$ vs. $3 \%$ for collagen.

HA is used to fill wrinkles and lip augmentation. Today the area of its application and usage in aesthetic medicine has expanded greatly, it is frequently used for volumization, nonsurgical facelift, correct dark circles and breast augmentation.

Also, HA is an important component of cartilage. In this role it dampens shocks in the joints, has lubrication effect and protects joints for chronic inflammation (eg arthritis). It is used to successfully heal stretching of ligaments. $\mathrm{HA}$ is a common ingredient in anti-osteoarthritis preparations and is frequently injected into joints, being a very effective treatment.

HA helps the immune system, acting as an antioxidant, it increases water retention in tissues, increases lubrication of heart valves, and serves as an adjunct to anti-infection treatment.

In the 1990s, hyaluronic acid began to be used in ophthalmology to treat corneal trauma.

Besides keeping joints lubricated, hyaluronic acid helps water retention in other tissues of the body, providing hydration of collagen and elastin. Interest in the use of HA as bioactive ingredient in skin care products came with the discovery that the volume of him in the skin decreases with age.

Clinically have been proven extraordinary efficiency of hyaluronic acid to fill wrinkles and smoothing. All clinical trials have shown that hyaluronic acid helps heal wounds faster and fading scars.

Currently procedures to inject cross-linked hyaluronic acid to fill wrinkles and lip augmentation, so-called fillers, are used [5]. For this purpose fits and are generally used products that are marketed as Amalian (Sweden), Perfectha (France) Remake (Italy), Aphrodite Gold (Germany) etc.

Unlike many other biologically active substances, HA shows all its valuable properties at very low concentrations ( 0.01 to $0.1 \%$ ), which allows to create effective cosmetics, whose prices will fit producers as well as consumers. This refers to high molecular weight HA, which are now part of moisturizing creams, lipsticks and lip balms, cellulite cream, sunscreen lotions, anti-inflammatory lotion and wound healing $[6,7]$.

HA content in the human body is an important factor on which the physiological process of aging and immunity of the body depends upon. To strengthen the immune system and prevent various diseases including cancer various 
"food additives" are prepared in which HA is used as an ingredient or as compound [8,9]. HA is called "star" of cosmetology, "hope" of rejuvenation and "pledge" of beauty. Benefits of Hyaluronic Acid supplementation - Cosmetic effect: Skin Hydration from the inside out, correcting in this way wrinkles. - Anti-arthritic: lubricate joints, especially knees and hips ones. - Rejuvenate, anti-aging effect: for men and women between 30 and 40 who are beginning to see signs of aging mirror. The effects are felt quickly after first supplementation with hyaluronic acid.

\section{Obtaining hyaluronic acid}

In world literature there is more information on specialized methods of obtaining and purification of hyaluronic acid.

Hyaluronic acid is contained in animal bodies tissues, extracellular matrix and cytoskeleton. Higher concentration of contained HA can be found in: synovial fluid, umbilical cord, bird crest, the vitreous of the eye, creating, skin, heart valves, cartilage of sharks and whales $[10,11]$. In all these tissues HA is accompanied by other mucopolysaccharides, which also form intermolecular compounds with collagen and other proteins. Main and most difficult problem in the process of obtaining $\mathrm{HA}$ is to remove as much as posible secondary components, including proteins, without affecting molecular weight of biopolymers.

For the first time HA was obtained and investigated in 1934 by K. Meyer and J. W. Palmer [12, 13], but increased interest in obtaining HA occurred after the World War II with the problem of eye vitreous substitutes search. In the monograph [14] are treated different methods of obtaining fetal umbilical cord HA based on the use of sodium acetate solution, dilute and concentrated solution of phenol, trichloroacetic acid, sodium chloride, pyridine, ferments etc. The preparation obtained was called "recovery factor", and later as a medicine it was called "Regenerator".

\subsection{Isolation of hyaluronic acid from umbilical cords}

One of the earliest methods of obtaining HA is described by Asatiani V.S. In his book [15] and consists of extraction of HA from umbilical cords. Umbilical cords are blood washed with water, then are dried and degrased with acetone. After grinding, HA extraction is done with water and sedimentation with acetone. Obtaining yield of this process is $6 \% \mathrm{HA}$ and relative viscosity of $1 \%$ solution is 3 .

The invention [16] Vunder P.A. and Muraşev A.N. improves the previous method. After grinding, washing, degreasing and dehydration, resulted umbilical cords are subject of extraction using boiling water for 5-15 min. For $2 \mathrm{~g}$ of dry weight, $200 \mathrm{~cm}^{3}$ of water are added. After cooling, the extract is centrifuged $15 \mathrm{~min}$ at a speed of $6000 \mathrm{rpm}$. HA is settled in the extract obtained with acetone in 1:4 volumetric ratio. $0.28 \mathrm{~g}$ sediment is obtained, containing HA and protein substances. The last are determined by the Lowry method. HA mass without protein is $10.2 \%$. Relative viscosity of the solution of $0.25 \%$ is 3 .

In the patent [17] authors Lutan V. and Bezdrîgin M. from State University of Medicine and Pharmacy "Nicolae Testemitanu" of the Republic of Moldova describe the method of obtaining of biocompatible HA from umbilical cords of fetuses for the medical use. Biological material is collected and preserved in $96 \%$ ethanol. After crushing, drying and washing procedures were performed at a temperature of $0-4^{\circ} \mathrm{C}$, authors extracted $\mathrm{HA}$ in saline $(0.89 \% \mathrm{NaCl}$ solution) to cold in three innings, then added to the obtained extract crystalline $\mathrm{NaCl}$ until a concentration of $25 \%$ is reached and ethanol in a proportion of 1:3 for HA sedimentation. HA obtained is recristalizat of 2 to 3 times of normal saline. Removing of the proteins is made using $\mathrm{CHCl}_{3}$ in proportion of $1: 2$ for 3-4 rounds until the solution remains transparent. After the last procedure of removing proteins is done, HA settles with 96\% ethanol (1:3). Product yield is not indicated. Protein concentration determined by Lowry method is $0.2 \mathrm{~g} / \mathrm{l}$, representing $5 \%$ of the total mass dissolved. Thus the authors consider that the content of HA is $95 \%(\mathrm{~m} / \mathrm{m})$. Relative viscosity of $0.2 \%$ HA solution is 5.0 . Absorption of $0.5 \%$ solution of $\mathrm{HA}$ at $257 \mathrm{~nm}$ (absorption maximum of nucleotides) is equal to 0.712 , and at $280 \mathrm{~nm}$ (absorption maximum of protein) is equal to 0.622 . Optical density spectra measured HA solution in 400-700 nm shows a maximum of 520$540 \mathrm{~nm}$, which is specific for hyaluronic acid. The authors have tested obtained biological product and demonstrated lack of toxicity, allergenic, hepatotoxic and cardiotoxic action, irritant action, action on the mineral metabolism.

\subsection{Isolation of hyaluronic acid from bovine vitreous}

Romanian patent [18] refers to a process of obtaining the HA and its sodium and potassium salts for cosmetic use from bovine vitreous humor. HA extraction is carried out with sodium para-xilensulfonat $10 \%$ weight of the material to be extracted. At a temperature of $60^{\circ} \mathrm{C}$, under vigorous stirring, until a homogeneous material is obtained (6-8 hours). After the material is cooled to $0-4{ }^{\circ} \mathrm{C}$ and with continuous stirring, it is treated with $\mathrm{HCl}$ solution to $\mathrm{pH} 3-3.5$ or with solution of $1 \mathrm{~mol} / 1 \mathrm{NaOH}, \mathrm{KOH}$ properly. After 24 hours material is filtered on bed hyflosupercel. If the filtrate obtained is colored, it treated with reactive charcoal and filtered again. Perfectly clear solution is cooled and treated with a volume of isopropyl alcohol. Settled HA is kept in cold for additional 24 hours, then isolated by centrifugation. It is then washed with acetone, isopropylalcohol andsterile, thendriedovercalciumchloride. Productyield from theinitialvolume of raw material was $0.04 \%$ $(\mathrm{w} / \mathrm{v})$. The authors state that the protein content in the product is $0.1-2 \%$. Treatment of merial with strong acid or base during extraction period changes strongly the environment. There are clear consequences. 


\subsection{Isolation of hyaluronic acid in the crest of birds and other connective tissues}

Balazs E.A. in 1979 reports about obtaining ultrapure high molecular weight HA from connective tissue of animal origin such as comb, umbilical cord [19]. The proposed method consists of extraction and purification of sodium hyaluronate in several consecutive steps, which takes longer and requires a large amount of work. Freshly collected raw material is washed thoroughly with water to remove blood completely, cut into small pieces and frozen at $-20-40^{\circ} \mathrm{C}$. While meterial os frozen it is finely grined and dehydrated in few rounds (no more than 3-4) with 95\% ethanol containing traces of chloroform (bacterial agent). Each wash-dehydration procedure takes 24 hours. Mass obtained is extracted twice with a mixture of water-chloroform $(20: 1, \mathrm{v} / \mathrm{v})$. An extraction takes 24 hours and is performed at a temperature of $4-25^{\circ} \mathrm{C}$. On $2.5 \mathrm{~kg}$ of processed raw materials are added for imbibition 101 of water and 0.51 of $\mathrm{CHCl}_{3}$, then for each extraction - at 15.751 mixture of chloroform-water. Prepared HA is separated from tissues using nylon filters. To remove proteins, crystalline $\mathrm{NaCl}$ is added to obtain a $10 \%$ solution. The author states that removal of proteins from extracted HA must be done with great caution as it can easily have destructive influence on macromolecule due to various external factors (ions of iron, oxygen and other oxidants that can penetrate the solution). Conditions for separation of proteins in solution were determined empirically and HA are considered optimal by the author. To the obtained solution chloroform is added in 1:1 ratio. Shaking of the mixture is made in a glass bowl for 3-5 hours with a Teflon stirrer (at 120-300 rpm) or vibration. Acid solution is maintained at $\mathrm{pH} 4-5$ by adding diluted $\mathrm{HCl}$ and an equal volume of $\mathrm{CHCl}_{3}$.

After 3-4 hours of stirring, the organic phase $\left(\mathrm{CHCl}_{3}\right)$ is removed with protein sediments at the surface layer of phase separation. This process is repeated several times until the chloroform layer remains clean after shaking. If the obtained extract contains an impressive amount of protein then author proposes to use enzymes. After the second treatment with $\mathrm{CHCl}_{3}$ of the extract, to the aqueous phase is added 50-100 g DNase enzymes and RNase, continuously stir a further 24 hours. After 24 hours bring the $\mathrm{pH}$ to 6-7 and 50-100 mg Pronase added. The solution still shake another 48 hours. In this way most of the proteins in the mixture are removed. If at the previous stage the extract was processed only with $\mathrm{CHCl}_{3}$ then $\mathrm{pH}$ is adjusted with $0.1 \mathrm{~N} \mathrm{NaOH}$ solution to $\mathrm{pH}$ 6-7. To the extract of $\mathrm{HA}$ with $\mathrm{pH}$ 6-7 an equal volume of chloroform is added and is shaked at $20-40{ }^{\circ} \mathrm{C}$ for five days. The author considers that full distortion of proteins and other components that can cause toxicity and inflammation occurs in five days. After removing $\mathrm{CHCl}_{3}$ layer in the aqueous phase remains only sodium hyaluronate. The obtained solution is centrifuged for 4 hours, filtered through sterile teflon filter (pore diameter $0.2 \mu \mathrm{m}$ ). To the obtained filtered solution 3 volumes of ethanol are added. HA settles and separates, then redissolves in 1.51 of doubly distilled water containing $0.1 \mathrm{~mol} \mathrm{NaCl}$ and settles again. This procedure is repeated 5 times. In the second redissolvation a $1 \%$ cetylpyridinium chloride is added in solution. After last redissolvation HA settles with 3 volumes of sterilized acetone then washed several times with sterilized acetone and obtained product is dried in vacuum. HA yield is $0.08 \%$. Protein content in the product $-0.4 \%$. Molecular weight determined $-1586000 \mathrm{D}$. absorbance of $1 \%$ aqueous solution where HA length $257 \mathrm{~nm}$ is 0.243 , and at $280 \mathrm{~nm}$ -0.198 .

His method allowed obtaining pharmaceutical preparation of HA with the trade name "Hea Lon" (Farmacia, Sweden), which up to date remains one of the best, but also the most expensive viscoprotector in ophthalmology surgery. A dose of $\mathrm{HA}$ required to perform a surgical operation is $0.4 \mathrm{~cm}^{3}$ of $1 \%$ solution.

According to the method presented in reference [20] crests of cocks are extracted twice with aqueous solution of $5-25 \%(\mathrm{v} / \mathrm{v})$ butyl or propyl alcohol and their isomers. Extraction takes about 32 hours. To the obtained extract crystalline $\mathrm{NaCl}$ was added to separate phases. $\mathrm{HA}$ is separated by sedimentation from aqueous phase with ethanol. Protein is less than $1 \%$, humidity - $15 \%$. Ultraviolet absorption in the solution of $1 \%$ at a wavelength $257 \mathrm{~nm}$ is less than 3.0 , and at $280 \mathrm{~nm}-$ less than 2. $\mathrm{pH}$ aqueous solution of HA obtained is 5.5 to 7.5. The degree of extraction of HA is $50 \%$, and efficiency is not indicated.

In reference [21] Laurent T.C. mentions that crests of cocks might contain up to $0.75 \%(\mathrm{~m} / \mathrm{m}) \mathrm{HA}$. In the vitreous of human eyes there are approximately $0.02 \%(\mathrm{w} / \mathrm{v}) \mathrm{HA}$.

According to the invention [22] cockscombs are extracted with water fowls or solution $1-15 \% \mathrm{NaCl}$ at a temperature of $80^{\circ} \mathrm{C}$, HA yield is $2 \%, 9 \%$ protein content. Extraction duration is approximately 24 hours.

According to the publication [23] cockscombs are extracted with water for 1-2 min at a temperature of $90-100^{\circ} \mathrm{C}$. The mixture obtained is cooled for $2-3$ hours to a temperature of $4-6^{\circ} \mathrm{C}$. Fat is removed, it is filtered and remnant is separated from the crests. To the obtained filtrate activated carbon is added at a rate of $1-2 \%$ of initial mass of raw material and is stirred $1-2$ hours. The mixture is filtered. To the obtained filtrate penicillin is added at a rate of $1-2 \%$ of the initial mass of raw material and maintain 18 to 24 hours at $20-22^{\circ} \mathrm{C}$, then dry. Yield is 3.8 to $4.0 \%$ from initial mass of raw material. Relative viscosity of $0.1 \%$ aqueous solution is 4.0 , the protein content $0.4-0.5 \%$.

Further Stecolnicov L. I. with his team proposes a new method to extract HA [24]. Unlike his previous method [23] authors performed the HA extraction at room temperature $20-22^{\circ} \mathrm{C}$, with water, in three stages, at the ratio of 1:(4-6 v) creasts : $\mathrm{H}_{2} \mathrm{O}$ for $2-4$ hours. Extracted HA is settled then with trichloroacetic acid in an amount of $1-2 \%$ to the volume of obtained extract. HA sediment is rising to the surface of the aqueous phase and protein settles to the bottom. HA is 
washed 3 times with acetone and diethyl ether $2-41$ in the report to $1 \mathrm{~kg}$ of raw material. Sediment is dried in air and then redissolved in water ( $2 \mathrm{v}$ for $1 \mathrm{~kg}$ of initial weight), filter and sublime. Yield is $5 \%$, protein content is $0.05 \%$ and the relative viscosity of $0.1 \%$ solution at $20^{\circ} \mathrm{C}$ is 6.0 .

The authors of the method [25] excludes alcohol for HA sedimentation from extracts. They performed extraction with 3 to 3.5 volumes of water acidulated with acetic acid to $\mathrm{pH} 3-4$ and temperature of $90-100^{\circ} \mathrm{C}$ for $40-60 \mathrm{~min}$. To the obtained extracts a 1.0 and $1.5 \%$ activated carbon and dietilaminoetilcellulose is added, corespondingly for $1-2$ hours at $60-80^{\circ} \mathrm{C}$. After removing of proteins the solution is filtered at a temperature of $30-40^{\circ} \mathrm{C}$ with filter paper, filter glass containing boron acetilcellulose sterile membranes and polyvinyl chloride. The obtained solution is dried by sublimation under aseptic conditions. HA yield obtained is 0.09 to $0.12 \%$. The contents of protein substances does not exceed $0.1 \%$ in HA and ovalbumin does not exceed $0.001 \%$. The content of total protein in preparations of HA was determined by Kjeldahl classical method and albumin content was determined with the solid phase immunoferment screening test with sensitivity of $0.5 \mathrm{ng} / \mathrm{cm}^{3}$. Relative viscosity of HA solution $0.1 \%$ at $20^{\circ} \mathrm{C}$ is $12-14$.

This method is powerful to obtain ultrapure HA, but it also includes some minuses like: using special glass filters from acetilceluloză and polyvinyl chloride. The method is long and difficult.

Another team of russian authors together with Samoilenco I.I. propose the following method for obtaining HA from umbilical cords and cocks comb [26]. The raw material from which the blood was removed is washed with cold water $\left(10-15^{\circ} \mathrm{C}\right)$, finely grined at the meat grinders and freeze until $-70^{\circ} \mathrm{C}$. Add two parts of water to one part of frozen mass and combination is heated for $15-25 \mathrm{~min}$ at a temperature of $95-100^{\circ} \mathrm{C}$, then is filtered through gauze layers or centrifuge. Remnant from the filter is again frozen at a temperature of $-70^{\circ} \mathrm{C}$, and the filtrate collected. To the frozen mass water is added again at a ratio of 1:1.5 and heat for $15-25 \mathrm{~min}$ at a temperature of $95-100^{\circ} \mathrm{C}$. The mixture is filtered through gauze, the filtrate is collected, and the rest of the filter is frozen again and again repeated three times, each time using water at the ratio of 1:1 against the remnant mass. Filtrates are joined and HA is removed at extract acidification with acetic acid. HA yield is 5\%. Protein content was determined by Lowry and it is $4 \%$, molecular mass is approximately equal to 1 million $\mathrm{D}$ and it was calculated using the characteristic viscosity. Product homogeneity was confirmed using Tindal effect. For better removal of the protein, the product was redissolved in dilute $\mathrm{NaOH}$ solution and ultrafiltered. HA solution was lyophilised. Summary yield decreases very small $(4.5 \%)$ and protein content decreases by 10 times.

In the method proposed in [27], after washing and degreasing with alcohol (1:2), peaks are crumbling and are subject to processing by ultrasound at a frequency of $16-20 \mathrm{kHz}$ for $5-10 \mathrm{~min}$. HA extraction is performed with water at a temperature of $45-50^{\circ} \mathrm{C}$ for $20-25 \mathrm{~min}$. Aqueous phase separation is achieved by vacuum filtration and sedimentation $\mathrm{HA}$ is obtained with $95 \%$ ethanol in volume ratio of 1:3. Aqueous solution is filtered and the filtrate is evaporated over the oxide of phosphorus $(\mathrm{V})$ in a vacuum. Yield is $11 \%$. The mass of protein is $0.4 \%$.

In [28] is presented a scheme for a process of obtaining the formaceutical form of the aqueous solution of HA with high molecular weight, for a certain concentration, sterilized.

This ultrafine purification scheme of HA is powerful, has many sophisticated stages, automated, and uses expensive technologies. In the local conditions at the present moment it is unlikely that it can be done.

In the invention [29] authors report about obtaining and purification of extra pure fractions of $\mathrm{HA}$ with applications in ophthalmic surgery. The proposed method is laborious and expensive. It includes the use of large amounts of solvents (ethanol, acetone), chelates use and their removal. The extraction and purification process using molecular sieves DOWEX M-15, Celita, or N-metilpirolidon or dimetilsulfoxid, methylene chloride, sodium chloride, cetilpiridină, $\mathrm{NaBr}, \mathrm{NaCl}$. Product yield is $0.6 \%$. Proteins are removed by fermentation using for this purpose enzymes (papain, pepsin, trypsin or pronaza). Determination of protein in the final product was done by Lowry method and is $-0.2 \%$. Were determined following parameters of the obtained product: static viscosity ranges between 14.5 to $21 \mathrm{D} / \mathrm{g}$ as measured by Viscometers Ubellodi at $25^{\circ} \mathrm{C}$ in solution of $0.15 \mathrm{~mol} / 1 \mathrm{NaCl}, \mathrm{pH} 7$ and corresponding mass molecular medium $(0.75-1.23) \cdot 10^{6} \mathrm{D}, 1 \%$ aqueous solution absorbance at a wavelength $\mathrm{HA} 257 \mathrm{~nm}$ and $280 \mathrm{~nm}$ does not exceed 1.0.

All these methods are of great scientific, but technological methods are still inconvenient because it requires large amounts of reagents, further removal of toxic reagents is difficult, yield is comparatively small.

So, the diversity of methods for obtaining hyaluronic acid in the laboratory is high, but there is no optimal method, reasonable technologies for extraction and purification of hyaluronic acid in industry.

\section{Procedure for obtaining hyaluronic acid and its derivatives for practical use in the pharmaceutical industry, food and cosmetics}

Properties of hyaluronic acid are determined by molecular mass, extraction mode, traces of proteins and other proteoglycans that can contaminate preparations obtained.

In research conducted hyaluronic acid was obtained from several natural sources of raw material: crest of hens $(\mathrm{CH})$, cockscomb (CC), bovine vitreous body (BVB), bovine umbilical cord (BUC) [30-32]. Obtain preparations of hyaluronic acid was performed according to the scheme of Fig. 2. 
In the proposed method the degreasing of raw material is carried out fully before extraction of HA, along with dehydration in Soxhlet apparatus with acetone for 2 hours. HA extraction is performed with $\mathrm{NaCl}$ solution only at cold $\left(4-10^{\circ} \mathrm{C}\right)$. From the obtained extract in cold, HA settles with $96 \%$ ethanol or acetone. The product is redissolved and proteins are remove by heating-cooling at $\mathrm{pH} 7$ and $\mathrm{pH} 5$ to 5.5 in $\mathrm{CHCl}_{3}$ processing. From the obtained solution is settled and isolated the sodium hyaluronate, HA respectively, with corresponding efficiency.

Characteristics of obtained preparations are vary depending on source of raw materials and obtaining method. For obtained samples was determined the mass part $(\omega)$ of hyaluronic acid in the raw material which was subjected to extraction, the protein mass (Lowry method) [33], relative viscosity (Ostwald method) [34] (Tab. 1, fig. 3).

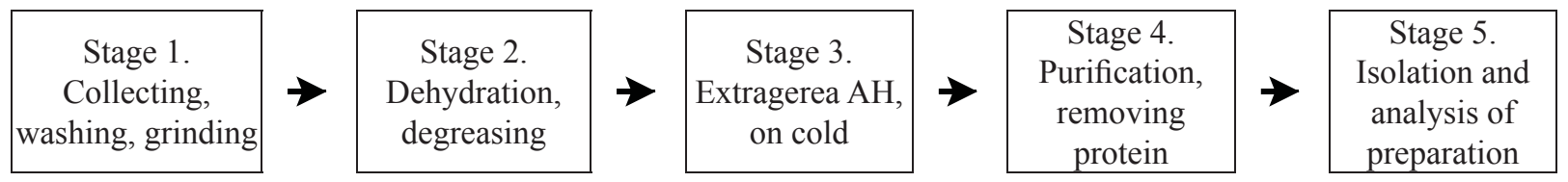

Fig. 2. Process scheme for obtaining hyaluronic acid

Table 1

Feature of HA preparations obtained from various sources of raw material

\begin{tabular}{|l|c|c|c|c|}
\hline & CH & CC & BVB & BUC \\
\hline$\omega(\%)$ & $0,5-0,7$ & $1,1-1,5$ & $0,1-0,2$ & $1,4-1,8$ \\
\hline Proteins $(\%)$ & $3-5$ & $1-3$ & $1-3$ & $2-4$ \\
\hline Relative viscosity $(\eta)$ & $11-12$ & $12-13$ & $5-7$ & $12-13$ \\
\hline
\end{tabular}

Identification of HA in the obtained preparations was made based on the infrared absorption spectra. IR spectra were recorded in the $4000-400 \mathrm{~cm}^{-1}$ for solid preparations, in $\mathrm{KBr}$ pills. (Fig. 2).

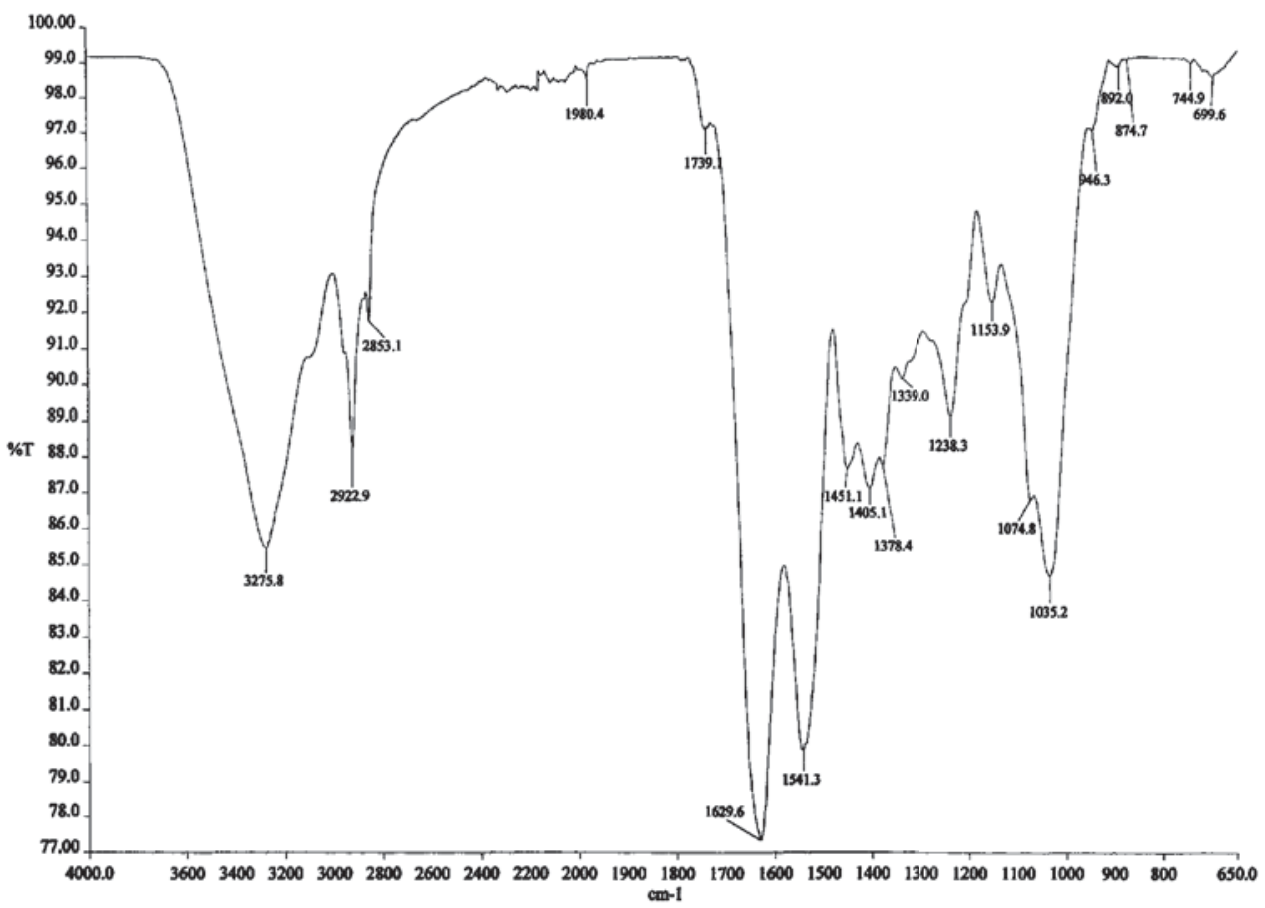

Fig. 3. IR spectrum of hyaluronic acid

In the domain $3400-3300 \mathrm{~cm}^{-1}\left(\max 3275.8 \mathrm{~cm}^{-1}\right)$ is obvious the large absorption band of symmetrical and asymmetrical valence oscillations of $\mathrm{OH}$ and $\mathrm{NH}$ groups linked by hydrogen bonds intra-and intermolecular. Absorption bands in the domain 3000-2800 $\mathrm{cm}^{-1}\left(\max 2922.9\right.$ and $\left.2853.1 \mathrm{~cm}^{-1}\right)$ are characteristic for valence oscillations of $\mathrm{CH}$ bonds in the macromolecule chain. The intensive absorption band at $1629.6 \mathrm{~cm}^{-1}$ is characteristic of carbonyls of valence oscillations of carboxyl group. Absorption bands 1405.1 and $1378.4 \mathrm{~cm}^{-1}$ are characteristic for oscillations of valence interaction of carbonyl group and the hydroxyl deformation oscillation plane of the carboxyl group. Are well defined bands with maximum absorption at 1541.3 and $1451.1 \mathrm{~cm}^{-1}$ (amide I, amide II) characteristic oscillations of the carbonyl group and N-acetyl-hexozamină CN chemical bonds, CCO and NCC. The absorption at $1238.3 \mathrm{~cm}^{-1}$ is characteristic 
of amides and is due to the valence oscillations of $\mathrm{CN}$ and $\mathrm{CO}$ bond. Summary absorption band $1100-1050 \mathrm{~cm}^{-1}$ with maximum $1035.2 \mathrm{~cm}^{-1}$ is characteristic for primary and secondary hydroxyl groups oscillations. The spectrum is well defined band $1153.9 \mathrm{~cm}^{-1}$ characteristic for the valence oscillations of COC bonds [35].

Taking into consideration the results of research and availability of raw material sources we have agreed to obtain hyaluronic acid from the crest of birds (hens and cocks) collected from local poultry companies [36-38].

Research result is the issuance process for obtaining HA, increasing the extraction, cost reduction, improving the quality of the final product suitable for use in medical, cosmetic and food.

Obtaining of HA was carried out in several stages as illustrated in Fig. 4.

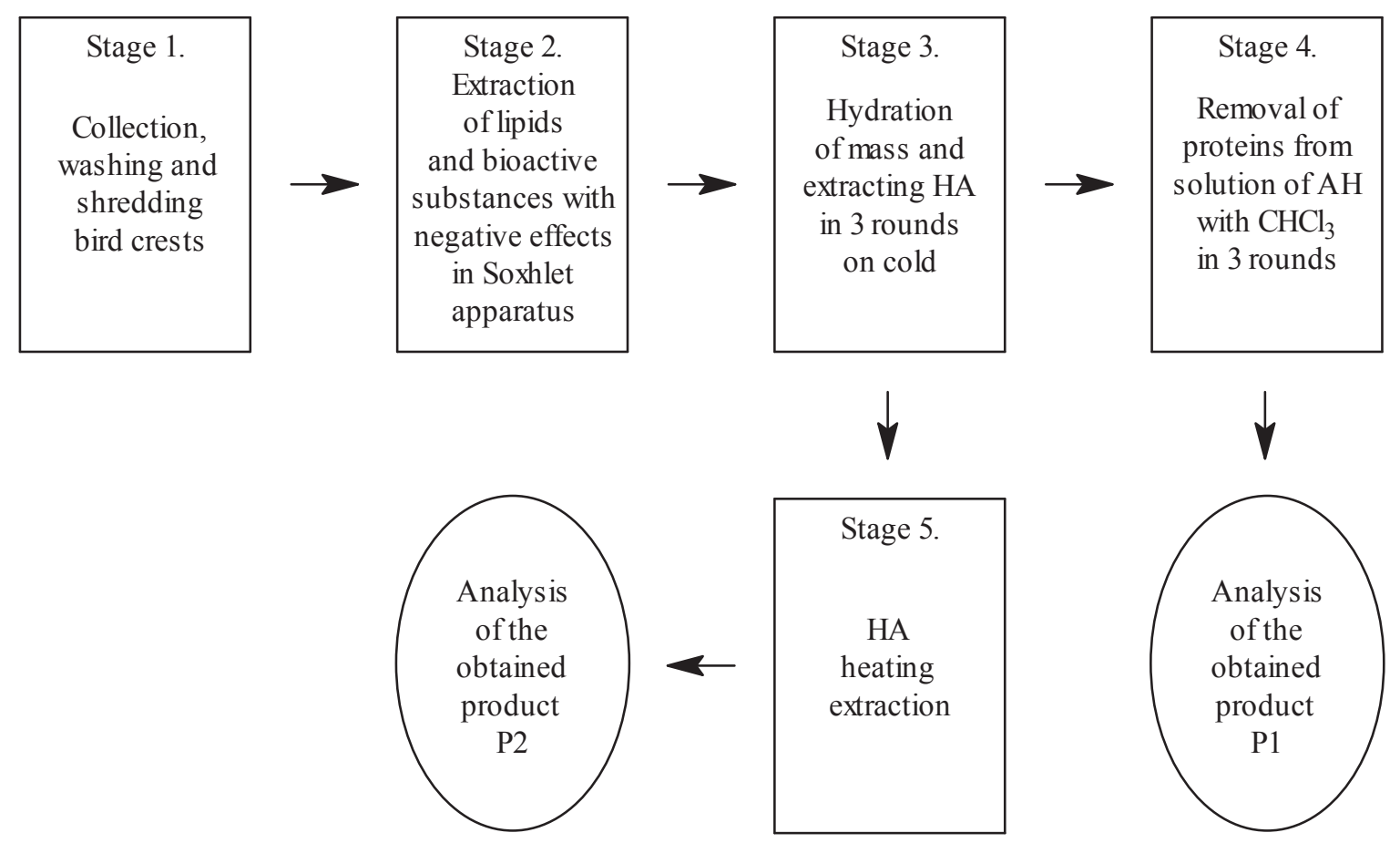

Fig. 4. Scheme process of obtaining and purification of hyaluronic acid and sodium hyaluronate

For this purpose $160 \mathrm{~g}$ of crests were collected from hens and cocks, immediately after healthy birds were slaughtered at the company Avicola "Roso" s. Floreni, Chisinau, were washing blood with cold water $\left(10-15^{\circ} \mathrm{C}\right)$ in 2-3 innings for 5-6 hours and then were chopped finely, so that fragment sizes were about $1-3 \mathrm{~mm}$. Grinding was performed in Moulinex Genius 2000 food processor. Shredded mass was added to acetone or $96 \%$ ethanol containing $1 \% \mathrm{CHCl}_{3}$ in the ratio of $1: 3$ and left in refrigerator for $6-24$ hours at $0-4^{\circ} \mathrm{C}$ (stage 1). As a result, the raw material was partially dehydrated and volume decreased. The solvent was distilled and separated, and partially dehydrated mass was introduced in Soxhlet apparatus and was extracted with acetone (stage 2). As the result further dehydration took place and concomitant extraction of bioactive substances soluble in acetone (lipids, phospholipids, lipoproteins, glicolipide, glicolipoproteine, nucleotides, enzymes, etc.) which can then contaminate the final product. After removal of all harmful bioactive substances the mass was removed from the machine and to dried in ventilation niche untill smell of acetone disappeared. The mass of the dried product is $37 \mathrm{~g}$.

As for $\mathrm{HA}$ extragent we used $1 \mathrm{M} \mathrm{NaCl}$ aqueous solution. The obtained dry mass $(37 \mathrm{~g})$ was added to $750 \mathrm{~cm}^{3} 1$ $\mathrm{M} \mathrm{NaCl}$ solution and 2-3 drops of $\mathrm{CHCl}_{3}$ as bacteriological agent. The mixture was left in the refrigerator for 24 hours at $4-10^{\circ} \mathrm{C}$. The mixture was filtered. The filtrate was collected and to the already hydrated mass of crests, a new portion of extragent and 2-3 drops of $\mathrm{CHCl}_{3}$ were added. Same procedure was repeated three times (stage 3). Remnant after extraction was frozen for further processing. The three extract portions were combined together (a total of 2 liters), were filtered through nylon mesh, centrifuged at $7000 \mathrm{rpm}$ for $20 \mathrm{~min}$ to remove insoluble impurities. The solution was cooled to $4^{\circ} \mathrm{C}$, pH was set at 5 to 5.5 with $0.1 \mathrm{M} \mathrm{HCl}$ solution and $96 \%$ cold ethanol in the ratio of 1:3 was added. The formed sediment was separated and dissolved in $100 \mathrm{~cm}^{3}$ of $1 \mathrm{M} \mathrm{NaCl}$ solution, was heated 5-10 min until the temperature of $70-80^{\circ} \mathrm{C}$ and then rapidly cooled to $18-20^{\circ} \mathrm{C}, \mathrm{pH}$ was adjusted to $5-5.5$ with $0.1 \mathrm{M} \mathrm{HCl}$ solution and $1: 1 \mathrm{CHCl} 3$ was added, was stirred gently with glass stirrer in one direction only, in the separating funnel. After 24 hours the upper aqueous phase was separated and was collected, the organic phase $\left(\mathrm{CHCl}_{3}\right)$ and proteins were sedimented at interphase and removed and the solvent was distilled. The procedure was repeated 3-4 times until the aqueous solution became transparent or slightly opalescent (stage 4). After the last procedure of removal of proteins $\mathrm{pH}$ was adjusted to 7.5-8.0 
with dilute $\mathrm{NaOH}$ and hyaluronic acid sedimented from the aqueous phase with cold $96 \%$ ethanol in the ratio of $1: 3$ in the form of salt sodium (P1). It was obtained $0.785 \mathrm{~g}$ of product. Obtined product $\mathrm{P} 1$ yield is $0.5 \%$. The protein mass determined by Lowry method in the final product does not exceed $1 \%$. IR spectrum confirms the authenticity of the product obtained HA (Fig. 4).

The 1\% HA aqueous solution obtained by the proposed method is a viscous liquid, eculent hard, transparent or slightly opalescent, colorless, odorless. Relative viscosity of the solution of $0.1 \%$ HA Ostwald Viscometers measured at a temperature of $18^{\circ} \mathrm{C}$ was equal to 12 .

$1 \%$ solution absorbance measured at $257 \mathrm{~nm}$ HA (absorption maximum nucleotide) and $280 \mathrm{~nm}$ (absorption maximum of protein) - is less than $0.1 \mathrm{a}(l=10 \mathrm{~mm})$.

Obtained hyaluronic acid is kept in $96 \%$ ethanol, in closed bottles protected from light at $0-4^{\circ} \mathrm{C}$ temperature.

Remnant from step 3 was thawed and added to it $700 \mathrm{~cm}^{3} 1 \mathrm{M} \mathrm{NaCl}$ solution and 2-3 drops of $\mathrm{CHCl}_{3}$. The mixture obtained was heated on a water bath at a temperature of $50-60^{\circ} \mathrm{C}$ for 3 hours (stage 5). Then the mixture was filtered through sterilized nylon mesh. The filtrate was centrifuged at $7000 \mathrm{rot} / \mathrm{min}$ for $30 \mathrm{~min}$.

It is viscous and was gelatinised in the refrigerator. To the obtained extract it was added acetone in the ratio of 1:3 (v/v). Sedimented product (P2) was separated, washed with acetone and dried. The analysis of obtained product P2 was carried using the same parameters as P1 product analysis. The results are presented in Table 2. The product P2 was carried out qualitative and quantitative analysis of protein content in amino acid analyzer. For analysis 58 mg of product were dissolved in $10 \mathrm{ml} \mathrm{P} 2$. It was found that the product P2 contains 64.7\% protein with composition shown in Table 3 . The $1 \%$ solution of the product P2 presents ultraviolet absorption at a wavelength $266.5 \mathrm{~nm}$ equal to 0.609 a. $(l=10$ $\mathrm{mm})$.

Hyaluronic acid was obtained from hens and cockscomb - shaped preparations:

P1 - sodium hyaluronate, P2 - hyaluronic acid-protein complex.

Table 2

Feature of obtained products

\begin{tabular}{|c|c|c|c|c|c|}
\hline $\mathrm{Nr} / \mathrm{o}$ & $\begin{array}{c}\text { Obtained } \\
\text { product }\end{array}$ & $\begin{array}{c}\text { Product yield } \\
(\%)\end{array}$ & $\begin{array}{c}\text { The protein } \\
\text { mass }(\%)\end{array}$ & $\begin{array}{c}\text { Relative viscosity } \\
\text { of the solution } \\
\left(18^{\circ} \mathrm{C}\right)\end{array}$ & $\begin{array}{c}\text { Kinematic } \\
\text { viscosity (St) }\end{array}$ \\
\hline 1 & P1 & 0,5 & 1 & 12 & 0,13 \\
\hline 2 & P2 & 12 & 64,7 & 13 & 0,14 \\
\hline
\end{tabular}

Table 3

Qualitative and quantitative composition of amino acids in the product P2

\begin{tabular}{|c|c|c|c|c|c|c|}
\hline & $\mu \mathrm{M} / 100 \mathrm{Mg}$ & $\mathrm{Mg} / 100 \mathrm{Mg}$ & $\mathrm{mM} / \mathrm{g}$ & $\begin{array}{c}\text { azot, } \\
\%\end{array}$ & $\begin{array}{c}\text { azot în } \\
\mathrm{Mg} / 100 \mathrm{Mg}\end{array}$ & $\begin{array}{c}\text { azot în } \\
\mathrm{Mg} / 0,1 \mathrm{Mg}\end{array}$ \\
\hline Aspartic acid * $^{*} 24,9318$ & 3,2935 & 0,2493 & 10,52 & 0,34904 & 0,3464 \\
\hline Threonine * $^{*}$ & 11,7768 & 1,4026 & 0,1178 & 11,76 & 0,16488 & 0,1649 \\
\hline Serine $^{*}$ & 15,9810 & 1,6796 & 0,1598 & 13,33 & 0,22373 & 0,2238 \\
\hline Glutamic acid * & 52,2660 & 7,6883 & 0,5227 & 9,52 & 0,73172 & 0,7319 \\
\hline Proline & 13,0443 & 1,5014 & 0,1304 & 12,17 & 0,18262 & 0,1827 \\
\hline Glycine & 261,0336 & 19,5958 & 2,6103 & 18,66 & 3,65447 & 3,6566 \\
\hline Alanine* & 53,1720 & 4,7371 & 0,5317 & 15,72 & 0,74441 & 0,7447 \\
\hline Valine* & 17,7482 & 2,0783 & 0,1775 & 11,96 & 0,24848 & 0,2486 \\
\hline Cysteine * & 46,7801 & 5,6206 & 0,4678 & 11,66 & 1,30984 & 0,6554 \\
\hline Methionine & 26,2385 & 3,9148 & 0,2624 & 9,39 & 0,36734 & 0,3676 \\
\hline Isoleucine & 12,5406 & 1,6453 & 0,1254 & 10,68 & 0,17557 & 0,1757 \\
\hline Leucine & 19,3458 & 2,5382 & 0,1935 & 10,68 & 0,27084 & 0,2711 \\
\hline Tyrosine & 15,2280 & 2,7593 & 0,1523 & 7,73 & 0,21319 & 0,2133 \\
\hline Phenylalanine & 11,2201 & 1,8536 & 0,1122 & 8,48 & 0,15708 & 0,1572 \\
\hline Lysine & 15,0103 & 2,1944 & 0,1501 & 19,16 & 0,42029 & 0,4204 \\
\hline Histidine & 7,6302 & 1,1839 & 0,0763 & 27,08 & 0,32047 & 0,3206 \\
\hline Tryptophan * & 3,0765 & 0,6282 & 0,0308 & 13,72 & 0,08614 & 0,0862 \\
\hline Arginine & 1,7756 & 0,3093 & 0,0178 & 32,16 & 0,09943 & 0,0995 \\
\hline Ammonia & 7,5397 & 0,1284 & 0,0754 & 82,24 & 0,10556 & 0,1056 \\
\hline$\Sigma$ aminoacids & 608,7993 & 64,6242 & 6,0880 & & 9,71955 & 9,1722 \\
\hline
\end{tabular}

The resulting products are used in further studies. 


\section{References}

[1]. Zadorojnâi L., Despre unele aspecte ale acidului hialuronic obținut din diverse surse naturale, Meridian Ingineresc, U.T.M., 2005, Nr. 2, pp. 54-57.

[2]. Byčkov S. M., Kuzmina S.A., Biologičeskaya rolı gialuronovoi kisloty (obzor), Voprosy medicinskoi himii, 1986, 32, № 1, 19-32.

[3]. Bezdrîgin M., Acțiunea biologică, biocompatibilitatea şi inofensivitatea acidului hialuronic obținut din diferite surse naturale. Realizări ştiințifice în farmacologie, Chişinău, 1999, pp 171-177.

[4]. Lutan V. ş.a., Acidul hialuronic - procedee biochimice, efectele biologice şi perspectivele utilizării în medicină, farmaceutică şi cosmetologie, Anale şstiintifice ale Universitaii de Stat de Medicina şi Farmacie "Nicolae Testemițeanu”, "Probleme medico-biologice şi farmaceutice" Vol. I, Chişinău, 2005, Ed. VI, 181-184.

[5]. Balazs E. A. et al., Cross-linked gels of hyaluronic acid and products containing such gels, Patent US 4636524, 1987.

[6]. Lebedeva E. M., Fedorischev I. A., Kompoziciya zaživleniya ran na osnove gialuronovoi kisloty, Patent RU2172168, 2001.

[7]. Lebedeva E. M., Fedorischev IA., Kompoziciya dlya uhoda za kožei lica, Patent RU2159111, 2000.

[8]. Brown K. K., Hyaluronic acid used as a cancer treatment, Patent WO9420115, 1994.

[9]. Folk R.E., Cancer treatment and metastasis prevention, Patent WO 9530423, 1995.

[10]. Ignatova E. IY., Gurov A. N., Principy izvlečeniya i očistki gialuronovoi kisloty, Himiko-farmacevtičeskii žurnal, 1990, 24, № 3, 42-46.

[11]. Uait A., Hendler F., Smit T. Э. i dr., Osnovy biohimii, per. s angl. T. 3.; M., 1981, s. 1489-1491.

[12]. Meyer K., Palmer J., W. J.Biol. Chem., 1934, 107, 629-634.

[13]. Meyer K., Palmer J., W. J.Biol. Chem., 1936, 114, 689-695.

[14]. Metody himii uglevodov, per. s angl., pod red. Kočetkova N.K.; M., "Mir”, 1967; s. 368-370.

[15]. Asatiani V. S., Fermentnye metody analiza, M., "Nauka", 1969, s. 566.

[16]. Vunder P. A., Murašev A. N., Sposob polučeniya gialuronovoi kisloty, Patent RU950735, 1982.

[17]. Lutan V., Bezdrâghin M., Procedeu de obținere a acidului hialuronic; Brevet MD1617, 2001.

[18]. Rădulescu G., Lupescu I., Petrea D. M., Scurei H., Panaitescu M., Procedeu de obținere a acidului hialuronic şi a sărurilor sale de sodiu sau potasiu, de uz cosmetic; Brevet RO116283, 1995.

[19]. Balazs E.A., Riverdale N.Y., Ultrapure hyaluronic acid and the use thereof; Patent US4141973, 1979.

[20]. Ryašencev V.IY., Nikolıskii S.F., Vainerman E.S. i dr., Sposob polučeniya gialuronovoi kisloty; Patent RU2017751, 1994.

[21]. Laurent T. C., Chemistry and Molekular Biology of the Intercellular Matrix, Vol.2; Academic Press: London, 1970; pp 730-763.

[22]. Muhtarov E. I., Tulupova G. B., Gromov I. IY., Sposob polučeniya preparata gialuronovoi kisloty, Patent RU2055079, 1996.

[23]. Stesolnikov L. I., Rylıcev V. V., Ignatiyk T. E. i dr., Sposob polučeniya gialuronovoi kisloty, Patent RU16116926, 1989.

[24]. Stesolnikov L. I., Rylbcev V. V., Virnik R. B. i dr., Sposob polučeniya gialuronovoi kisloty, Patent RU2046801, 1995.

[25]. Stesolnikov L. I., Samoilenko I. I., Kornilova A. A., Sposob polučeniya gialuronovoi kisloty, Patent RU2074196, 1997.

[26]. Samoilenko I. I., Epifanov A. E., Sposob polučeniya gialuronovoi kisloty, Patent RU2115662, 1998.

[27]. Antipova L. V., Polyanskih S. V., Aleksiyk M. P., Sposob polučeniya gialuronovoi kisloty, Patent RU2114862, 1998.

[28]. Carlino Stefano, Process for preparing a sterile high molecular weight Hyaluronic acid formulation, Patent WO2004014399, 2004.

[29]. Aurelio Romeo, Silvana Lorencii, Frakciya gialuronovoi kisloty ili eë soli, sposob očistki эtoi frakcii, sposoby polučeniya эtoi frakcii, farmacevtičeskii preparat i sredstva, ispolszuemye v oftalımologii, Patent RU2128666, 1999.

[30]. Zadorojnâi L. Zadorojnâi A. The comparative investigation of methods for separation and purification of hyaluronic acid from diferent natural sources, Presentations on II $^{\text {nd }}$ International Conference of the Chemical Society of the Republic of Moldova "Achievements and Perspectives of Modern Chemistry", Chişinău, October 1-3, 2007, p.44.

[31]. Zadorojnâi L. Zadorojnâi A. Studiu comparativ a preparatelor de acid hialuronic obținute din diverse surse de materie primă locală; Teze la Conferința Tehnico-Ştiințifică a Colaboratorilor, Doctoranzilor şi Studenților, Chişinău, U.T.M., 15-17 noiembrie, 2007, Vol. II, pp. 12-13. 
[32]. Zadorojnâi L., Zadorojnâi A., Analiza comparativă a preparatelor de acid hialuronic obținute din diverse surse de materie primă; Book of Abstracts XXX-th Romanian Chemistry Conference; Călimăneşti-Căciulata, Rm.Vâlcea, România, 8-10 octombrie, 2008, p. 30.

[33]. Filippovič IY. B., Egorova T. A., Sevastıyanova G. A., Praktikum po obschei biohimii; M., Prosveschenie, 1975; s.75-76.

[34]. Rabek YA., Эksperimentalınye metody v himii polimerov, č. I; M., izd. MIR, 1983; c. 131-139.

[35]. Nakanisi K., Infrakrasnye spektry i stroenie organičeskih soedinenii. Per. s angl. Kupletskoi N.B. i Эpštein; M., Izd-vo "Mir"; 1965.

[36]. Zadorojnâi L., Procedeu de obtinere a acidului hialuronic, hialuronatului de sodiu si complexului acid hialuronicproteine; Brevet MD 3099, 2006; BOPI, № 7, p.29.

[37]. Zadorojnâi L., Sturza R., Zadorojnâi A., Obținerea acidului hialuronic din surse naturale locale. Teze la Conferința Ştiințifică Internațională "Învăţământul superior şi cercetarea - piloni ai societăţii bazate pe cunoaştere". Rezumatele comunicărilor, Ştiinţe reale Chişinău, 28 septembrie, 2006, p. 157.

[38]. Zadorojnâi L., Sturza R., Zadorojnâi A., Procedeu de obținere a acidului hialuronic, Teze la Conferința Jubiliară Tehnico-Ştiințifică a Colaboratorilor, Doctoranzilor şi Studenților consacrată celei de-a 40-a Aniversări a Doctoranturii U.T.M., Chişinău, 17-18 noiembrie, 2006, Vol. II, pp. 29-31. 